\title{
Characterization and Potential of Coelogyne rochussenii Orchids from Bukit Rimbang and Bukit Baling Wildlife Sanctuary as Explant Source
}

\author{
Pebra Heriansyah", Gusti Marlina \\ Islamic University of Kuantan Singingi. Jl. Gatot Subroto Km. 7, Kebun Nenas, Teluk Kuantan, Sungai Jering, Kuantan Singingi, \\ 29566, Riau, Indonesia \\ *Corresponding author. E-mail address: hpebra92@gmail.com
}

\section{ARTICLE HISTORY:}

Received: 22 September 2020

Peer review completed: 13 October 2020 Received in revised form: 19 October 2020 Accepted: 23 January 2021

\section{KEYWORDS:}

Ex-situ conservation Physiologically mature

Young pseudobulbs

(C) 2021 The Author(s). Published by Department of Forestry, Faculty of Agriculture, University of Lampung in collaboration with Indonesia Network for Agroforestry Education (INAFE).

This is an open access article under the CC BY-NC license:

https://creativecommons.org/licenses/by$\mathrm{nc} / 4.0 /$.

\begin{abstract}
Conservation is an effort to return natural resources to their habitat to restore the ecosystem balance, which can be done in-situ and ex-situ. Coelogyne rochussenii orchid conservation efforts are essential to maintain its sustainability. The purpose of this study was to characterize $C$. rochussenii orchids from Bukit Rimbang and Bukit Baling Wildlife Sanctuary as a source of tissue culture explants to support ex-situ conservation efforts. Orchid plant samples were obtained through exploration in three locations with an altitude of 92 masl, and then the characterization of leaf morphology, pseudobulbs, roots, and fruit were carried out. The characterization results showed that the young pseudobulbs, young leaves, healthy roots, and physiologically ripe fruits of the C. rochussenii orchids obtained could be used as a source of explants to support ex-situ conservation efforts.
\end{abstract}

\section{Introduction}

Coelogyne rochussenii is a type of orchid that has decreased in population. One of the causes of the decline in the population of $C$. rochussenii orchids is the reduction in forest area, as happened in Singapore (Tay et al. 2019). Forest area decline has also occurred in Bukit Rimbang and Bukit Baling Wildlife Sanctuary, Riau. Suandy et al. (2014) reported degradation of the buffer areas in Bukit Rimbang and Bukit Baling Wildlife Sanctuary within four years, reaching 82.25\%. One of the impacts of the decrease in both primary and secondary forests is a decrease in the $C$. rochussenii orchids population in Bukit Rimbang and Bukit Baling Wildlife Sanctuary. Apart from C. foertermannii, Eria biflora, Dipodium sp., Bulbophyllum spp, and Acriopsis liliifolia. Puspitaningtyas (2009) reported that $C$. rochussenii orchids are also one of the epiphytic orchids dominating the Bukit Rimbang and Bukit Baling Wildlife Sanctuary. Therefore, conservation efforts towards the preservation of $C$. rochussenii orchids are critical. Conservation is an effort to return natural resources to their habitat to return the ecosystem balance (Crouzeilles et al. 2020). Conservation efforts can be carried out by the level of damage to these resources, either in-situ or ex-situ. The conservation efforts can be selected according to the needs and damage level (Leclère et al. 2020). Ex-situ conservation of C. rochussenii orchid in Bukit Rimbang and Bukit Baling Wildlife Sanctuary is more suitable than in-situ. Some obstacles to in-situ conservation efforts are the lack of suitable host trees and the presence of associated mycorrhizal fungi (Yeung 2017). 
Based on this, ex-situ conservation efforts for C. rochussenii orchids are needed, one of which is tissue culture.

Tissue culture is a propagation technique that can be used to overcome a limited number of planting material produced in a short time with good plant quality. Because aseptic concepts in the process support it, the use of this technique in conservation efforts is possible because it has a vast opportunity to reproduce plants with a low failure rate. This technique also does not require large amounts of planting material, but the results can be in the millions (Ghosh et al. 2018). Various kinds of orchid species have been successfully propagated through tissue cultures, such as Dendrobium lasianthera (Utami et al. 2017), Phalaenopsis amabilis, Coelogyne pandurata, and Vanda tricolor, Phalaenopsis amboinensis (Utami and Hariyanto 2019), and Epipactis flava orchid (Kunakhonnuruk et al. 2018).

Propagation by tissue culture involves several vital processes, including selecting explants to be planted on tissue culture media. Explants to be planted need to be selected morphologically and environmentally to be acceptable for later culture (Hu et al.2017). Explants that will be planted in tissue culture propagation can be in the form of root, stem, leaf, or seed tissue. Various sources of explants are used in orchid propagation.

Explants of orchid seeds play an essential role in orchid plants reproduce in vitro because each seed can grow, germinate, and form a callus. One can contain millions of pieces of orchid seeds. However, the drawback of implanted in vivo growth was highly dependent on symbiosis with mycorrhizal fungi because the seeds have no endosperm. The use of seed explants has been successfully done in Cymbidium aloifolium orchid (Bhowmik and Rahman 2020a), Coelogyne asperata orchid, Coelogyne celebensis, Coelogyne foerstermannii, Coelogyne pandurata, Coelogyne pulverula, Coelogyne rumphii, Coelogyne rochussenii (Puspitaningtyas and Handini 2014). Pseudobulb explants as part of orchid organs that have the potential to form embryo somatic, or protocorms like bodies, from protocorm like bodies, will be able to form hundreds of embryo somatically subcultured and form ready to plantlets, such as the use of pseudobulbs in Pleione maculata (Chauhan and Sharma 2017), Malaxis acuminata D. Don (Deb and Arenmongla 2014), Lycaste aromatica (Graham ex Hook) (Mata-Rosas et al. 2010), Cymbidium finlaysonianum (Islam et al. 2015), Coelogyne flaccida Lindl. (Kaur and Bhutani 2013), and Dendrobium kingianum Bidwill (Prażak and Molas 2015).

Planting leaves as the center of photosynthetic activity can form various plant formations, both callus and embryo somatic. This is because there are thousands of cells capable of differentiating to realize cell totipotency in young leaves, such as the use of leaves in tissue culture of Aerides multiflora orchids (Bhowmik and Rahman 2020a), Dimorphorchis lowii orchids (Jainol and Gansau 2017), Phalaenopsis cv. Surabaya (Balilashaki et al. 2015), orchid Dendrobium sp (Goswami et al. 2016), Rhynchostylis retusa (L.) Blume orchid (Islam et al. 2015), Dendrobium Sonia orchid (Juntada et al. 2015), Phalaenopsis sp. orchid (Zahara 2017). Apart from leaves, roots also have the potential to be used as explants. This is because cells in orchid roots have an excellent response to differentiation processes, especially adventitious roots, such as root culture in Cyrtopodium paludicolum orchids (Picolotto et al. 2017), Rhynchostylis retusa's orchids (Kurniasari et al. 2019). Consequently, the purpose of this study to characterize C. rochussenii orchids from Bukit Rimbang and Bukit Baling Wildlife Sanctuary, Riau, as a source of tissue culture explants in support of ex-situ conservation efforts. 


\section{Materials and Methods}

The Coelogyne rochussenii orchid sample used in this study was obtained through exploration in Bukit Rimbang and Bukit Baling Wildlife Sanctuary at an altitude of 90-160 meters above sea level (masl) (Fig. 1). The orchids found were subsequently characterized morphologically, including root organs, stems, leaves, and fruit. The identification of orchids was carried out by reference (Comber 2001). The selected orchid plant samples were then taken for exsitu conservation efforts at the Tissue Culture Laboratory, Horticulture Main Seed Center, Agricultural Service, Riau Province as a living collection. The explants obtained will be reproduced using seed culture and stored until they are ready to be introduced back into their original habitat.
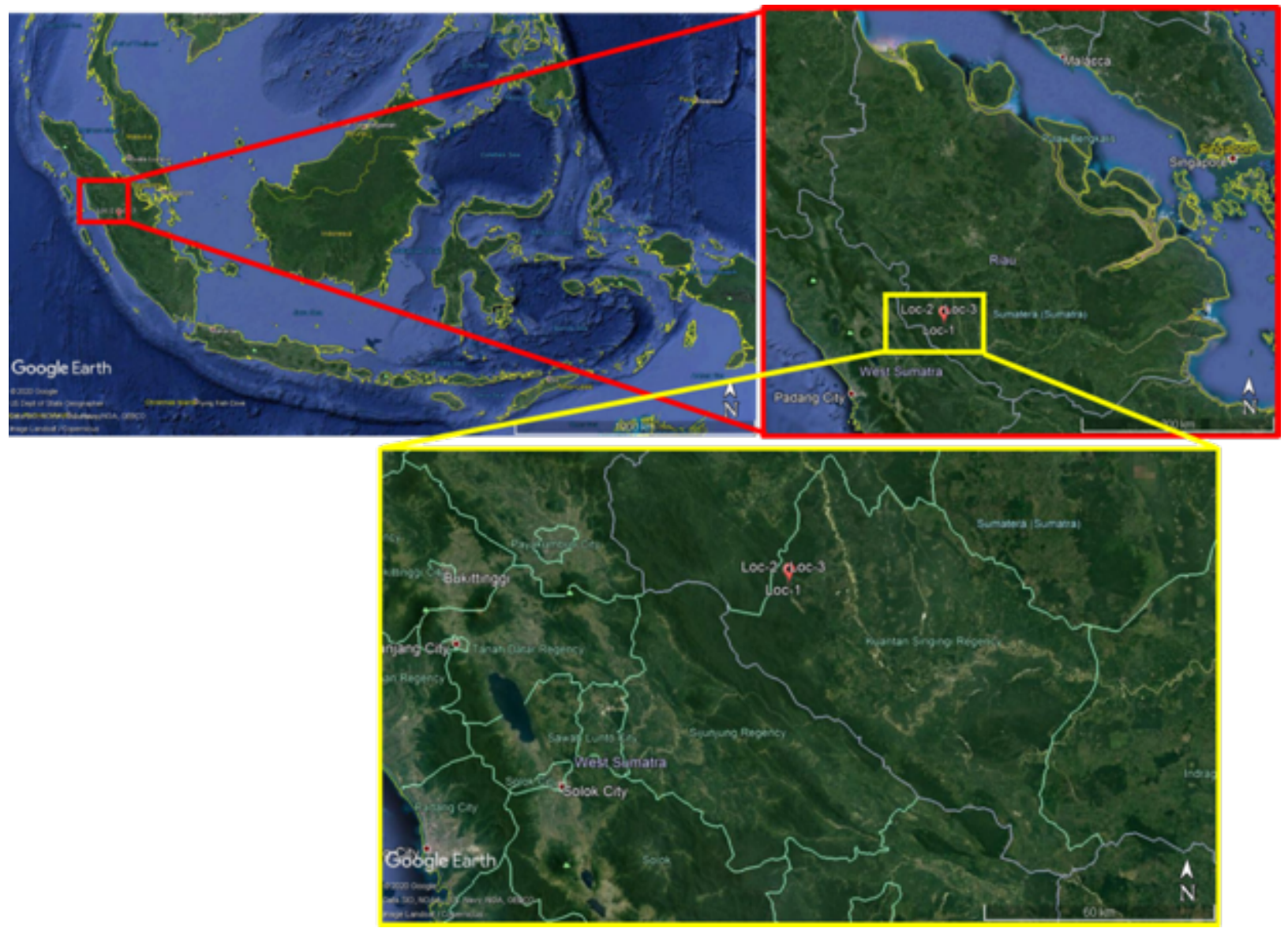

Fig. 1. Location of the Coelogyne rochussenii natural orchid inventory in Bukit Rimbang and Bukit Baling Wildlife Sanctuary, Riau (Source: Google Earth).

\section{Results and Discussion}

Bukit Rimbang and Bukit Baling Wildlife Sanctuary are designated as wildlife reserves based on the Decree of the Minister of Forestry Number 3977/Menhut-VIII/KUH/2014. It is located in the Kampar Regency and Kuantan Singingi Regency, Riau Province, with an area of 141,226.25 ha (BBKSDA Riau 2020). This area is a buffer for forest ecosystems with an average temperature of $18-240^{\circ} \mathrm{C}$, a relative humidity of $39-64 \%$, and light of $474 \mathrm{~A}-716 \mathrm{~B}$ (Noverita et al. 2019). Bukit Rimbang and Bukit Baling Wildlife Sanctuary is a habitat for thousands of plants, including orchids. In this area, there are reported to be 21 genera and 49 species of orchids. Among the types of orchids that live in this area, there are 43 species, including epiphytic orchids and three 
types of ground orchids (Puspitaningtyas 2009). One of the orchids found in Bukit Rimbang and Bukit Baling Wildlife Sanctuary is Coelogyne rochussenii (Fig. 2). The results of the exploration carried out in this study showed that $C$. rochussenii orchids were found at all three points with an altitude of 92 masl (Table 1). Puspitaningtyas (2009) also reported that $C$. rochussenii could grow at an altitude of 128-160 masl in Bukit Rimbang and Bukit Baling Wildlife Sanctuary. Meanwhile, Isnaini et al. (2015) also reported that $C$. rochussenii orchids were found on Abang Island and its surroundings, Batam, Riau Islands, at an altitude of 21 masl.

Table 1. Locations of $C$. rochussenii orchid in Bukit Rimbang and Bukit Baling Wildlife Sanctuary, Riau

\begin{tabular}{cccc}
\hline Description & Location 1 & Location 2 & Location 3 \\
\hline Coordinate & S: $00^{\circ} 18^{\prime} 59.61^{\prime}$ & S: $00^{\circ} 18^{\prime} 59.60^{\prime \prime}$ & S: $00^{\circ} 18^{\prime} 59.62^{\prime \prime}$ \\
& E: $101^{\circ} 11^{\prime} 03.75^{\prime}$ & E: $101^{\circ} 11^{\prime} 03.744^{\prime}$ & E $101^{\circ} 11^{\prime} 03.76^{\prime}$ \\
Altitude from sea level (masl) & 92 & 92 & 92 \\
\hline
\end{tabular}
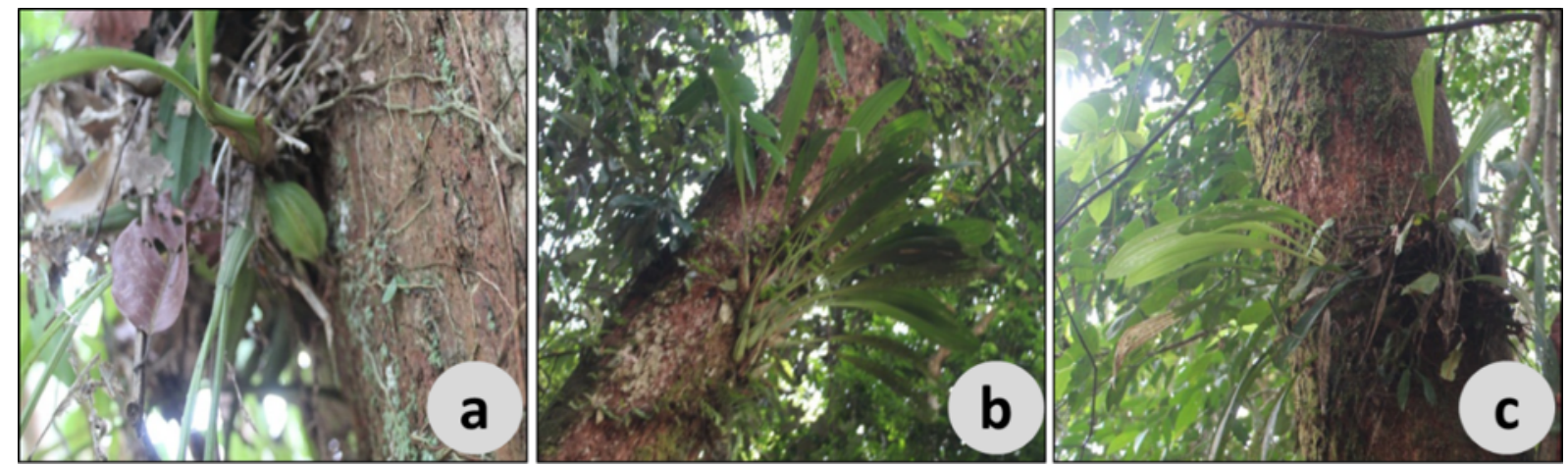

Fig. 2. C. rochussenii orchids found in (a) Location 1, (b) Location 2, and (c) Location 3 in Bukit Rimbang and Bukit Baling Wildlife Wildlife Sanctuary.

C. rochussenii orchid is an epiphytic orchid with a sympodial type. The rhizome spreads and branches out. The bulb of the $C$. rochussenii orchid is oval, the leaves emerge from the tip of the bulb, and each bulb supports two leaves. The leaves of the C. rochussenii orchid are oblong with a pointed tip. According to Hartini and Wawangningrum (2019), pendulous inflorescences on $C$. rochussenii orchids emerge from the stem's base and dangle 20-35 flowers bloom together with a yellowish-green color.

The morphology of this orchid plant is characterized by the presence of a rhizome at the root where the pseudobulb grows. The distance between the rhizomes is $3-5 \mathrm{~cm}$ between the parts. This pseudobulb orchid is oval-shaped with two leaves growing every one pseudobulb. This section is a place to store food reserves for $C$. rochussenii orchids during the dry season so that in the dry season, the pseudobulb appears wrinkled. The leaves have 5-7 leaf bones arranged in the middle of the leaf, the length of the plant leaves is $20-18 \mathrm{~cm}$, the leaf width is $10-15 \mathrm{~cm}$. with a wide tarpaulin half apical, narrowing gradually to the base and petiole, $5-8 \mathrm{~cm}$ long. This plant's flower is stunning with a 5.0-5.2 cm size, characterized by pale greenish-yellow and pale sepals and petals, then white labellum decorated with brown color to the inside. This adds to the charm of this tiny orchid. C. rochussenii orchids bloom all year round, bloom in the morning, and bud in the afternoon. The flowers have a strong fragrance, with light jasmine and musky scent. This aroma in its natural habitat will invite insects to pollinate the flowers (Lok et al. 2011). 
This plant has dangling flowers and was first named by the Dutch East Indies Governor named J. J. Rochussen. He immortalized his name for the naming of this orchid plant. This naming also goes hand in hand with the promotion of Johannes Elias Teijsmann (1809-1882) and Simon Binnendijik (1821-1883) works for the description of the C. rochussenii plant. Since then, this orchid has been widely known throughout Asia to Europe because it was widely introduced by the Dutch East Indies (Clayton 2002).

The habitat of $C$. rochussenii orchids spread from the Himalayas and South China, Sri Lanka, most of Southeast Asia, and east of the Pacific islands (Comber 2001). Meanwhile, according to Clayton (2002), C. rochussenii orchids are spread from Palaan Philippines, Peninsular Malaysia, Singapore, Kalimantan, most of Sumatra, Java, the northern tip of Sulawesi, and Maluku, to southern Thailand. Coelogyne rochussenii belongs to the subfamily Epidendroideae, species Coelogyneae, and subspecies Coelogyninae, a genus Dendrochilum, Pholidota, and Pleione, which is sometimes difficult to distinguish from Coelogyne species when present in a vegetative state. Coelogyne has also been further divided into 22 sections (Lok et al. 2011).

The $C$. rochusseni orchid has a wide distribution area, making its population abundant in nature. However, in reality, human activities and various environmental impacts are increasingly pressing this plant's population. Chong et al. (2009) reported that C. rochussenii is now declared extinct nationally. According to herbarium records, C. rochussenii was only collected four times in Singapore and all in the late 1890s, with the last collection in 1894. The C. rochussenii orchid in Malaysia is reported to have become extinct locally. This is due to this orchid's selling price resulting in excessive plundering of its habitat (Majit et al. 2014).

\subsection{Description of C. rochussenii in Location 1}

The $C$. rochussenii orchids were found in Location 1 with an altitude of 92 masl, as many as eight plants. The orchids found in Location 1 were at a host height of $8 \mathrm{~m}$. As an ex-situ conservation effort for $C$. rochussenii orchids from this area, it is known that one physiologically ripe fruit, two young pseudobulbs, four young leaves, and healthy roots have the potential to be used as a source of tissue culture explants (Table 2).

Table 2. Morphological characteristics of C. rochussenii orchid found in Bukit Rimbang and Bukit Baling Wildlife Sanctuary, Riau

\begin{tabular}{lccc}
\hline \multirow{2}{*}{ Character } & \multicolumn{3}{c}{ C. rochussenii } \\
\cline { 2 - 4 } & Location 1 & Location 2 & Location 3 \\
\hline Host height (m) & 8 & 10 & 12.5 \\
Number of old leaves & 12 & 14 & 12 \\
Number of young leaves & 4 & 8 & 2 \\
Number of leaves disturbed & 2 & 3 & 3 \\
(damaged) & 6 & 7 & 6 \\
The number of old pseudobulbs & 2 & 4 & 1 \\
Number of young pseudobulbs & 1 & 2 & 2 \\
The number of pseudobulbs is & 1 & 0 & 0 \\
disturbed (damaged) & Not Disturbed & Not Disturbed & Not Disturbed \\
Number of fruit & \multicolumn{2}{c}{} \\
Root state & &
\end{tabular}


Observation at Location 1 found one remaining orchid with three stalks of fruit had fallen off. The orchids found at this location have good morphological characteristics, including no pest disturbance on the fruit skin, yellowish-green rind due to the ripening process. If allowed to age, this ripe orchid will break and release its small seeds flying down. Some fall onto other branches carried away by the wind. However, seeds cannot germinate independently but must have a symbiosis with mycorrhizal fungi because these seeds do not only contain embryos, and there is no endosperm as food reserves. This makes it challenging to increase the number of orchid populations in the field (Wu et al. 2020).

The level of fruit development indicated as physiologically ripe can be seen from the yellow seeds of the C. rochussenii orchid. However, morphologically the fruit is still green with a slightly yellow tinge on the edges and corners (Fig. 3). The observed characteristics indicate that the $C$. rochussenii orchid fruit has the potential to be used as a source of explants in tissue culture. Suriya et al. (2017) stated that if placed on the right media, physiologically ripe orchid seeds would experience a good germination process. One of the things that need to be considered in the use of tissue culture explants in the form of seeds is the level of maturity (Wu et al. 2020). However, in addition to the level of seed maturity, the parent plant's physiological and morphological conditions also determine the success rate of orchid tissue culture (Mose et al. 2017). According to Deb and Temjensangba (2006), tissue culture of the Malaxis khasiana Soland orchid using an explant source in the form of seeds showed a success rate of up to $75 \%$ after 107 days of culture.

The seeds of $C$. rochussenii are the most significant opportunity for orchid conservation activities in Bukit Rimbang and Bukit Baling Wildlife Sanctuary areas ex-situ. In one orchid, it stores millions of embryos that we can develop into complete plants. Various obstacles in in-situ conservation can be overcome by using seed tissue culture techniques. These orchid seeds can also be used as stored genetic material, which can be reused at any time. Ex-situ conservation stages include surveying the potential explants in the field, explant isolation, aseptic culture, and acclimatization. The next activity is the reintroduction of orchids to the area (Puspitaningtyas and Handini 2014).

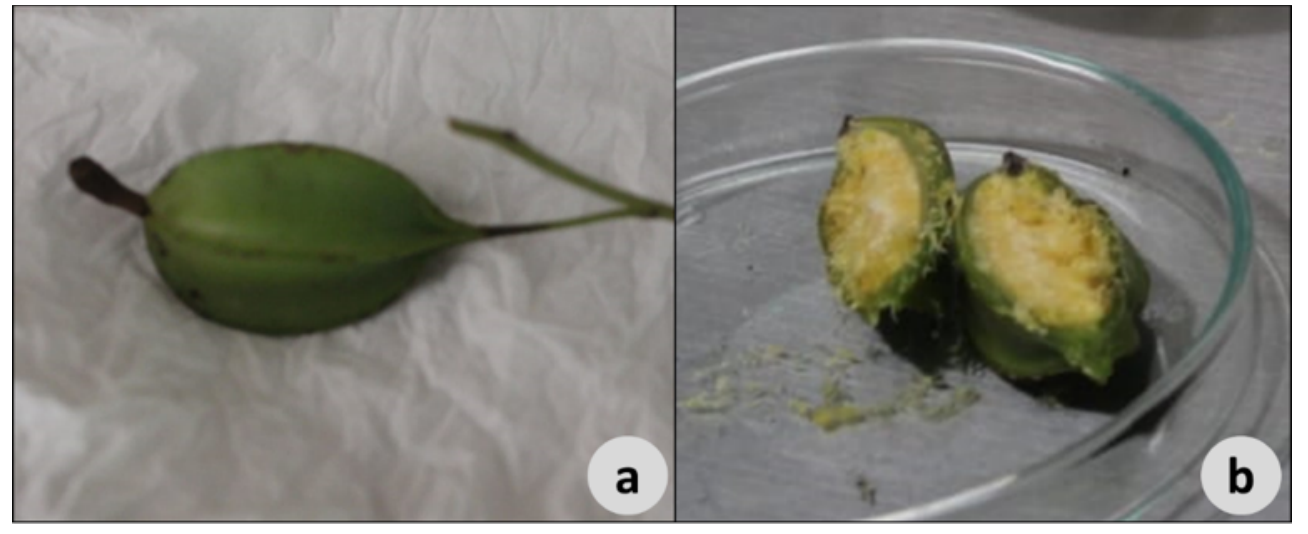

Fig. 3. (a) Orchid fruit that will be used as explants and (b) seeds of $C$. Rochussenii orchid found in Bukit Rimbang and Bukit Baling Wildlife Sanctuary, Riau.

\subsection{Description of C. rochussenii in Location 2}

The C. rochussenii orchids found in Location 2 live epiphytes with a host height of 10 meters. Based on the observations, it was indicated that the orchid was still in the vegetative phase because there were no signs of remaining flowering, such as stalks and traces of plant knobs. 
Orchids found in Location 2 also can be used as a source of explants in ex-situ conservation efforts, namely four young pseudobulbs, eight young leaves, and healthy roots (Table 2).

The C. rochussenii orchid habitat in Bukit Rimbang and Bukit Baling Wildlife Sanctuary is disturbed because it is prone to disturbance. The presence of its hosts is scattered on the edge of the area directly adjacent to community activities. This can be seen from the difficulty of finding the orchid host of $C$. rochussenii. The condition is in line with the research results by Destri et al. (2015), C. rochussenii habitat conditions. The Bangka Belitung Islands are also experiencing disturbances so that this orchid is only found between the rocks. This certainly indicates a disturbance to the plant host.

The results of the $C$. rochussenii plant observations at Location 2 were fairly good because the host plant had a thick bark that allowed the plant roots to take nutrients from the residue of stem bark weathering. Besides, host plant litter that falls and is left around plant roots after rotting can also increase nutrient availability in orchid plants. Natural obstacles are often encountered in the field of rotting wooden branches, which then fall and hit the orchids so that they fall to the ground. This condition is not under their habitat; hence it will result in the death of the orchid. In general, the orchid hosts of the Coelogyne species are Pandanus sarasinorum, Ficus sp, Dracaena nagustifolia, and Magnolia candoleii (Ramadanil 2010).

Pseudobulbs are a potential source of explants to be grown on tissue culture media. However, the success rate of pseudobulbs as a source of explants was influenced by age. Young pseudobulb age and smaller explant size correlate with the increasing success rate of tissue culture (Anuprabha et al. 2017; Bhowmik and Rahman 2020b). Basker and Bai (2006) stated that tissue culture of the Coelogyne stricta orchid using an explant source in the form of pseudobulbs was able to produce shoot length growth of $4.40 \mathrm{~cm}$, number of shoots reaching 66 , number of roots 7 , and root length of $3.54 \mathrm{~cm}$ after 90 days after planting.

\subsection{Description of C. rochussenii in Location 3}

The $C$. rochussenii orchid found in Location 3 was found at a host height of 12.5 meters. The results showed that the orchids in Location 3 were more mature than those found in Location 1 and Location 2. This is indicated by the former flowering found in the form of dried flower stalks at the pseudobulb base. The orchid plant organs in Location 3 that can be used as a source of explants in ex-situ conservation efforts are a young pseudobulb, two young leaves, and healthy roots (Table 2).

The C. rochussenii orchid's morphological appearance at Location 3 shows that the plant has completed the flowering and fertilization process so that the plant's physical condition looks a little wrinkled in its pseudobulb. This happens because the plant's generative process leaves only a few nutrients for the plant. Another condition that occurs is that there is a disturbance in the leaves. This is because the plant's location is not far from the branching, so there is a lot of insect activity so that some old leaves are found disturbed. The young leaves' condition is not disturbed because they are in the inner grove. Young leaves can be used as a source of explants because the leaf cells are still meristematic, making it possible to develop into complete plants by initiating the formation of protocorm-like bodies (Shen et al. 2018). According to Budisantoso et al. (2017), using explants in the form of leaves in the Vanda sp orchid tissue culture could produce callus up to $83 \%$ after 14 days after culture. 
Apart from fruit, young pseudobulbs, and young leaves, roots can be used as a source of explants in tissue culture. The $C$. rochussenii orchid found in the three research locations in Bukit Rimbang and Bukit Baling Wildlife Sanctuary, Riau, has the potential to be used as a source of explants because the roots are still healthy (Table 2). The use of root explants in the Cattleya hybrid orchid tissue culture could produce somatic embryos with a height of $3 \mathrm{~cm}$ after eight weeks after culture (Sharma 2012). However, although they were able to show success in developing into individual candidate plants, root explants were known to have a lower success rate than other explant sources in in-vitro orchid propagation. The main obstacle to propagating orchids through tissue culture with a source of explants in the form of roots is still high in contamination (Pindel and Pindel 2004). This is because the root organs contain many contaminants that are difficult to overcome, even with sterilization (Gangrong 2004). Based on this, a particular treatment is needed to overcome the contamination of root explants in tissue culture. However, according to Chugh et al. (2009), root meristems in orchids have great potential in forming protocorm-like bodies.

The success of ex-situ conservation through tissue culture is strongly influenced by the explants' quality isolated from their natural habitat. Dwiyani (2015) stated that if fruit explants are used, it is necessary to pay attention to fruit maturity, both morphologically and physiologically. When using vegetative organs such as roots, rhizomes, pseudobulbs, and leaves, it is necessary to pay attention to these organs' health, free from pathogens that interfere and become contaminants when cultured. The level of maturity of cells in these organs will also affect the success in conducting tissue culture. The younger a cell in an organ, the faster the growth of the explants will be. The explants' size also determines the culture's success and its formation that will be done after initiation on tissue culture media, such as Murashige and Scoog, Knudson C, Vacin and Went, and other media. The last thing to pay attention to is the explant storage technique before it reaches the laboratory and the water content needs to be considered so that the plants are not damaged (Bhowmik and Rahman 2020a).

\section{Conclusions}

The Coelogyne rochussenii De Vriese orchid found in three locations in Bukit Rimbang and Bukit Baling Wildlife Sanctuary has the potential to be a source of explants in ex-situ conservation efforts. Four kinds of explants can be used in the conservation of C. rochussenii orchids, namely one physiologically ripe fruit, seven young pseudobulbs, fourteen young leaves, and healthy roots.

\section{Acknowledgments}

The authors thank the Deputy for Strengthening Research and Development Ministry of Research and Technology/National Research and Innovation Agency (RISTEK-BRIN), who has funded research activities through the Beginner Lecturer Research (PDP) scheme for funding in 2020. The authors also appreciate the Center for Natural Resources Conservation (BBKSDA), which has supported and granted permission to implement this research.

\section{References}

Anuprabha, P.P., Prakash, A., and Kumar, J. 2017. Regeneration Competence of Dendrobium nobile Lindl. through Pseudobulb Segments: A Study In Vitro. The Journal of the Orchid 
Society of India 31: 71-75.

Balilashaki, K., Vahedi, M., and Karimi, R. 2015. In Vitro Direct Regeneration from Node and Leaf Explants of Phalaenopsis cv. "Surabaya." Plant Tissue Culture and Biotechnology 25(2): 193-205. DOI: 10.3329/ptcb.v25i2.26254

Basker, S., and Bai, V.N. 2006. Micropropagation of Coelogyne stricta (D. Don) Schltr. Viapseudobulb Segment Cultures. Tropical and Subtropical Agroecosystems 6(1): 31-35.

BBKSDA Riau. 2020. Suaka Margasatwa Bukit Rimbang - Bukit Baling. Balai Besar Konservasi Sumber Daya Alam Riau.

Bhowmik, T.K., and Rahman, M.M. 2020a. In Vitro Study of Medicinally Important Orchid Aerides multiflora Roxb. from Nodal and Leaf Explants. Journal of Pharmacognosy and Phytochemistry 9(4): 179-184.

Bhowmik, T.K., and Rahman, M.M. 2020b. Micropropagation of Commercially Important Orchid Dendrobium palpebrae Lindl. through In Vitro Developed Pseudobulb Culture. Journal of Advanced Biotechnology and Experimental Therapeutics 3(3): 225-232.

Budisantoso, I., Amalia, N., and Kamsinah, K. 2017. In Vitro Callus Induction from Leaf Explants of Vanda sp. Stimulated by 2,4-D. Biosaintifika: Journal of Biology \& Biology Education 9(3): 492-497. DOI: 10.15294/biosaintifika.v9i3.11018

Chauhan, S., and Sharma, S. 2017. Conservation of Rare and Threatened Therapeutically Important Orchid Pleione maculata (Lindl.) Lindl. \& Paxton through Pseudobulb Culture In Vitro. Indian Journal of Scientific Research 15(1): 22-26.

Chong, K.Y., Tan, H.T.W., and Corlett, R.T. 2009. A Checklist of the Total Vascular Plant Flora of Singapore: Native, Naturalised and Cultivated Species. Raffles Museum of Biodiversity Research, National University of Singapore, Singapore.

Chugh, S., Guha, S., and Rao, I.U. 2009. Micropropagation of Orchids: A Review on the Potential of Different Explants. Scientia Horticulturae 122(4): 507-520. DOI: 10.1016/j.scienta.2009.07.016

Clayton, D. 2002. The Genus Coelogyne: A Synopsis. Natural History Publication, Michigan, USA.

Comber, J.B. 2001. Orchids of Sumatra. Royal Botanic Gardens, Kew, UK.

Crouzeilles, R., Maurenza, D., Prieto, P.V, Barros, F.S.M., Jakovac, C., Ferreira, M.S., Chazdon, R.L., Lindenmayer, D.B., Brancalion, P.H.S., Ceccon, E., Adams, C., Lazos-Chavero, E., Monteiro, L., Junqueira, A.B., Strassburg, B.B.N., and Guariguata, M.R. 2020. Associations Between Socio-Environmental Factors and Landscape-Scale Biodiversity Recovery in Naturally Regenerating Tropical and Subtropical Forests. in: Conservation Letters: A Journal of Society for Conservation Biology 1-9. DOI: 10.1111/conl.12768

Deb, C.R., and Arenmongla, T. 2014. Development of Cost Effective In Vitro Regeneration Protocol of Malaxis acuminata D. Don a Therapeutically Important Orchid Using Pseudobulbs as Explant Source. Journal of Plant Studies 3(2): 13-22. DOI: 10.5539/jps.v3n2p13

Deb, C.R., and Temjensangba. 2006. In Vitro Propagation of Threatened Terrestrial Orchid, Malaxis khasiana Soland ex. Swartz through Immature Seed Culture. Indian Journal of Experimental Biology 44(9): 762-6.

Destri, Fudola, Harto, A., and Kusnadi. 2015. Survei Keanekaragaman Anggrek (Orchidaceae) di Kabupaten Bangka Tengah dan Belitung, Provinsi Kepulauan Bangka Belitung. in: Prosiding Seminar Nasional Masyarakat Biodiversitas Indonesia 509-514. 
Dwiyani, R. 2015. Perkecambahan Biji dan Pertumbuhan Protokorm Anggrek dari Buah dengan Umur yang Berbeda pada Media Kultur yang Diperkaya dengan Ekstrak Tomat. Jurnal Hortikultura Indonesia 4(2): 90-93. DOI: 10.29244/jhi.4.2.90-93

Gangrong, S. 2004. Ecological Effects of Plant Root Exudates. Chinese Journal of Ecology 23(1): 97-101.

Ghosh, A., Igamberdiev, A.U., and Debnath, S.C. 2018. Thidiazuron-Induced Somatic Embryogenesis and Changes of Antioxidant Properties in Tissue Cultures of Half-High Blueberry Plants. Scientific Reports 8(1): 1-11. DOI: 10.1038/s41598-018-35233-6

Goswami, K., Yasmin, S., Nasiruddin, K.M., Khatun, F., and Akte, J. 2016. In Vitro Regeneration of Dendrobium sp. of Orchid using Leaf Tip as Explant. Journal of Environmental Science and Natural Resources 8(2): 75-78. DOI: 10.3329/jesnr.v8i2.26869

Hartini, S., and Wawangningrum, H. 2019. Orchids From Mount Sago Nature Reserve, West Sumatera. in: The SATREPS Conference 137-145.

Hu, W., Fagundez, S., Katin-Grazzini, L., Li, Y., Li, W., Chen, Y., Wang, X., Deng, Z., Xie, S., McAvoy, R.J., and Li, Y. 2017. Endogenous Auxin and Its Manipulation Influence in Vitro Shoot Organogenesis of Citrus Epicotyl Explants. Horticulture Research 4(1): 1-6. DOI: 10.1038/hortres.2017.71

Islam, S.M.S., Islam, T., Bhattacharjee, B., Mondal, T.K., and Subramaniam, S. 2015. In Vitro Pseudobulb Based Micropropagation for Mass development of Cymbidium finlaysonianum Lindl. Emirates Journal of Food and Agriculture 27(6): 469-474. DOI: 10.9755/ejfa.2015.04.017

Isnaini, Y., Wahyuni, S., and Wanda, I.F. 2015. Inventory of Orchids in Small Islands of the Abang Island and Its Surrounding, Batam, Riau Archipelago. Seminar Nasional Masyarakat Biodiversitas Indonesia 1(8): 2039-2043.

Jainol, J.E., and Gansau, J.A. 2017. Embryogenic Callus Induction from Leaf Tip Explants and Protocorm-Like Body Formation and Shoot Proliferation of Dimorphorchis lowii: Borneon Endemic Orchid. Agrivita 39(1): 1-10. DOI: 10.17503/agrivita.v39i1.895

Juntada, K., Taboonmee, S., Meetum, P., Poomjae, S., and Chiangmai, P.N. 2015. Somatic Embryogenesis Induction from Protocorm-Like Bodies and Leaf Segments of Dendrobium Sonia "Earsakul." Science, Engineering and Health Studies (University Science and Technology Journal) 9(2): 9-19.

Kaur, S., and Bhutani, K.K. 2013. In Vitro Mass Propagation of Ornamentally and Medicinally Important Coelogyne flaccida Lindl. through Pseudobulb Segments. Plant Tissue Culture and Biotechnology 23(1): 39-47. DOI: 10.3329/ptcb.v23i1.15558

Kunakhonnuruk, B., Inthima, P., and Kongbangkerd, A. 2018. In Vitro Propagation of Epipactis Flava Seidenf., an Endangered Rheophytic Orchid: A First Study on Factors Affecting Asymbiotic Seed Germination, Seedling Development and Greenhouse Acclimatization. Plant Cell, Tissue and Organ Culture 135(3): 419-432. DOI: 10.1007/s11240-018-1475-9

Kurniasari, D., Astuti, Yulianti, E., Suyitno, Sugiyarto, L., and Mercuriani, I.S. 2019. Increasing Rhynchostylis Retusa's Callus Formation by Immersing Explant in Ascorbic Acid and Planting on Activated Charcoal Contained Medium. in: Journal of Physics: Conference Series 1-8. DOI: 10.1088/1742-6596/1241/1/012060

Leclère, D., Obersteiner, M., Barrett, M., Butchart, S.H.M., Chaudhary, A., De Palma, A., DeClerck, F.A.J., Di Marco, M., Doelman, J.C., Dürauer, M., Freeman, R., Harfoot, M., Hasegawa, T., Hellweg, S., Hilbers, J.P., Hill, S.L.L., Humpenöder, F., Jennings, N., 
Krisztin, T., Mace, G.M., Ohashi, H., Popp, A., Purvis, A., Schipper, A.M., Tabeau, A., Valin, H., van Meijl, H., van Zeist, W.J., Visconti, P., Alkemade, R., Almond, R., Bunting, G., Burgess, N.D., Cornell, S.E., Di Fulvio, F., Ferrier, S., Fritz, S., Fujimori, S., Grooten, M., Harwood, T., Havlík, P., Herrero, M., Hoskins, A.J., Jung, M., Kram, T., Lotze-Campen, H., Matsui, T., Meyer, C., Nel, D., Newbold, T., Schmidt-Traub, G., Stehfest, E., Strassburg, B.B.N., van Vuuren, D.P., Ware, C., Watson, J.E.M., Wu, W., and Young, L. 2020. Bending the Curve of Terrestrial Biodiversity Needs an Integrated Strategy. Nature 585(7826): 551556. DOI: 10.1038/s41586-020-2705-y

Lok, A.F.S.L., Ang, W.F., Chong, K.Y., Yeo, C.K., and Tan, H.T. 2011. Rediscovery in Singapore of Coelogyne rochussenii de Vriese (Orchidaceae). Nature in Singapore 4: 49-53.

Majit, H.F., Lamb, A., Miadin, R., and Suleiman, M. 2014. The Wild Orchids of Crocker Range National Park, Sabah, Malaysia. Malayan Nature Journal 66(4): 440-462.

Mata-Rosas, M., Baltazar-García, R.J., Moon, P., Hietz, P., and Luna-Monterrojo, V.E. 2010. In Vitro Regeneration of Lycaste aromatica (Graham ex Hook) Lindl. (Orchidaceae) from Pseudobulb Sections. Plant Biotechnology Reports 4(2): 157-163. DOI: 10.1007/s11816010-0132-5

Mose, W., Indrianto, A., Purwantoro, A., and Semiarti, E. 2017. The Influence of Thidiazuron on Direct Somatic Embryo Formation from Various Types of Explant in Phalaenopsis amabilis (L.) Blume Orchid. HAYATI Journal of Biosciences 24(4): 201-205. DOI: 10.1016/j.hjb.2017.11.005

Noverita, N., Armanda, D.P., Matondang, I., Setia, T.M., and Wati, R. 2019. Keanekaragaman dan Potensi Jamur Makro di Kawasan Suaka Margasatwa Bukit Rimbang Bukit Baling (SMBRBB) Propinsi Riau, Sumatera. Pro-Life 6(1): 26-43. DOI: 10.33541/prolife.v6i1.935

Picolotto, D.R.N., Neto, V.B. de P., de Barros, F., Padilha, D.R.C., da Cruz, A.C.F., and Otoni, W.C. 2017. Micropropagation of Cyrtopodium paludicolum (Orchidaceae) from Root Tip Explants. Crop Breeding and Applied Biotechnology 17(3): 191-197. DOI: 10.1590/1984$70332017 \mathrm{v} 17 \mathrm{n} 3 \mathrm{a} 30$

Pindel, A., and Pindel, Z. 2004. Initiation of in Vitro Cultures of Chosen Endangered European Species of Orchids. Folia Horticulturae 16(2): 111-117.

Prażak, R., and Molas, J. 2015. Effect of Copper Concentration on Micropropagation and Accumulation of Some Metals in the Dendrobium kingianum Bidwill Orchid. Journal of Elementology 20(3): 693-703. DOI: 10.5601/jelem.2014.19.4.748

Puspitaningtyas, D.M. 2009. Eksplorasi Tumbuhan di Kawasan Suaka Margasatwa Bukit Rimbang Baling - Riau. Prosiding Seminar Nasional Biologi XX dan Kongres PBI XIV UIN Malik, Malang 1986(1731): 167-173.

Puspitaningtyas, D.M., and Handini, E. 2014. Penyimpanan Biji Anggrek Coelogyne spp. untuk Konservasi Ex Situ. Buletin Kebun Raya 17(2): 101-112. DOI: 10.14203/bkr.v17i2.142

Ramadanil. 2010. Kajian Beberapa Aspek Botani Anggrek Endemik Coelogyne celebensis J . J . Sm . dari Taman Nasional Lore Lindu Sulawesi Tengah. Biocelebes 4(1): 1-13.

Sharma, V. 2012. Regenerative Competence in Root Explants of Cattleya Hybrid, an Endangered Genera: A Study In Vitro. International Journal of Scientific and Research Publications 2(12): 1-3.

Shen, H.J., Chen, J.T., Chung, H.H., and Chang, W.C. 2018. Plant Regeneration via Direct Somatic Embryogenesis from Leaf Explants of Tolumnia Louise Elmore "Elsa." Botanical 
Studies 59(4): 1-7. DOI: 10.1186/s40529-018-0220-3

Suandy, I., Mulyadi, A., Moersidik, S.S., and Suganda, E. 2014. Degradasi Lingkungan di Kawasan Penyangga Suaka Margasatwa Bukit Rimbang Bukit Baling Provinsi Riau. Jurnal Ilmu Lingkungan 8(2): 214-225.

Suriya, K., Philip Robinson, J., Sebastinraj, J., and Kakati, J.P. 2017. In vitro seed germination of Cymbidium aloifolium (L.) Sw., a potential medicinal Orchid from Eastern Ghats of Tamil Nadu, India. Journal of Plant Biotechnology. DOI: 10.5010/JPB.2017.44.3.343

Tay, S., He, J., and Yam, T.W. 2019. CAM Plasticity in Epiphytic Tropical Orchid Species Responding to Environmental Stress. Botanical Studies 60(7): 1-15. DOI: 10.1186/s40529019-0255-0

Utami, E.S.W., and Hariyanto, S. 2019. In Vitro Seed Germination and Seedling Development of a Rare Indonesian Native Orchid Phalaenopsis amboinensis J.J.Sm. Scientifica 2019: 1-6. DOI: $10.1155 / 2019 / 8105138$

Utami, E.S.W., Hariyanto, S., and Manuhara, Y.S.W. 2017. In Vitro Propagation of the Endangered Medicinal Orchid, Dendrobium lasianthera J.J.Sm Through Mature Seed Culture. Asian Pacific Journal of Tropical Biomedicine 7(5): 406-410. DOI: 10.1016/j.apjtb.2017.01.011

Wu, W.L., Hsiao, Y.Y., Lu, H.C., Liang, C.K., Fu, C.H., Huang, T.H., Chuang, M.H., Chen, L.J., Liu, Z.J., and Tsai, W.C. 2020. Expression Regulation of Malate Synthase Involved in Glyoxylate Cycle during Protocorm Development in Phalaenopsis aphrodite (Orchidaceae). Scientific Reports 10(1): 1-15. DOI: 10.1038/s41598-020-66932-8

Yeung, E.C. 2017. A Perspective on Orchid Seed and Protocorm Development. Botanical Studies 58(33): 1-14. DOI: 10.1186/s40529-017-0188-4

Zahara, M. 2017. A Review: Micropropagation of Phalaenopsis sp from Leaf and Flower Stalk Explants. Jurnal Natural 17(2): 91-95. DOI: 10.24815/jn.v0i0.8130 